\title{
Cultivation of College Student National Principle with National Music
}

\author{
Rong Liu \\ College of music, Neijiang Normal University, Neijiang, China \\ 147981264@qq.com
}

Keywords: Chinese national music, National spirit, University Students.

\begin{abstract}
Chinese national music is a great treasure in China history. It embodies national spirit, will, and dream. For university students, it is important and necessary to cultivate natonal spirit by learnig Chinese national music through various kinds of method.
\end{abstract}

\section{Introduction}

The Chinese nation has 5000-year splendid civilization with the national music as a great treasure created in long-term labor by all ethnic groups, integrating national principle, national will and reflecting national pursuit. With constant ideological transition in various historical periods, the national music has been enriched, developed and improved. College students should get familiar with the national music culture, enhancing its cultivation and national principle.

\section{Current college music culture}

In recent years, the college campus culture has witnessed constant development and prosperity, with music serving an indispensable part of college life. Multiple college students are keen on pop music, including elegant styles, sound and up-to-date pop songs. However, some pop songs, as special products in the economic restructuring period, focus on emptiness and impetuousness in the community, negatively effecting some young people, making them take hypocritical as popular, vulgar as nice, unreasonable as cool. However, some outstanding national music is excluded as "antiques" by some college students under the influence of pop music and rock and roll. In a sense, neglect of national music will lead to defects of the overall quality and impact all-round development. To this end, it is necessary to colleges to make up the class of national music, vigorously promoting the national music culture, emphasizing the national music education, making college students receive sound aesthetic education.

\section{National music importance}

\subsection{Enhancing college student music quality and overall quality}

With 5,000-year civilization as the cultural deposits, Chinese national music can be described as voluminous, broad and profound. It is not only the source of all kinds of music creation, but also the foundation for development of various musical cultures. Strengthening national music education can enrich college student national culture, broadening student cultural horizons, cultivating student sound aesthetic taste and ability to distinguish between elegance and vulgarity, tradition and modernity, inheritance and innovation. Famous composer Beethoven said, "National music is a higher revelation than any wisdom or philosophy." Making student often contact beautiful and pure national music can purify ideas, cultivating sentiments, resulting in noble character, playing an underestimated education role. 


\subsection{Strengthening college student national awareness and patriotism}

As the essence of the national culture, national music embodies the national principle, temperament, psychological quality, customs and aesthetic taste. Our national music is characterized by a long history, distinctive creation, form, and genre, reflecting our national aesthetic concept. Appreciation of national music can experience and absorb unique principle, temperament and charm of the Chinese nation, strengthening national consciousness. Appreciating folk music can make college student enjoy music beauty, appreciating magnificent scenery of the motherland and rich customs of various ethnic groups. Conducting national music education is an effective way to strengthen college student 'national awareness, stimulating patriotism and national pride.

\subsection{Helping college student with establishing correct world outlook, outlook on life and values}

For college students, college life is an important period to form the world outlook, outlook on life and values. During this period, students are relatively simple with unstable ideals. National music infects and educates them with its vivid musical image with its unshakable power. The special language of national music can enlighten college students, purifying their hearts and minds, cultivating their mental and physical literacy, world outlook, outlook on life and values. Multiple new works of national music constantly emerge, reflecting and celebrating life, enriching and developing our national music, and more importantly, enhancing our confidence and patriotism, individuality and personality.

\section{Basic methods of applying national music to develop national principle}

\subsection{Cultivating national music faculty}

Teachers colleges are the cradles of various basic talents. Ability and quality of their graduates directly affect development of the basic education. Cultivating qualified music teachers especially national music teachers is one of the most effective ways to improve college student national music teaching. National music faculty with theoretical knowledge of national music, familiar with opera and folk music can sing a certain number of national songs, teaching different national musical works, helping students with establishing basic appreciation ability of national music, developing sound music appreciation habits.

\subsection{Stimulating college student interest in learning national music}

Music means touching. Unaffectionate teaching can not cultivate student interest. It is necessary to offer national music, making students understand pop music can not be separated from national music, and national music is the source of music creation, making them psychologically admire national music and develop their emotional recognition. Marko, a famous composer, pointed out, "All great musicians always follow the methods and directions suggested by the folk music for further artistic processing, rather than taking the opposite direction." Therefore, national music teaching should inherit this practice, leading students to trace the origin and background of these musical creations, guiding students to favor national music, inspiring their patriotic sentiment and efforts for the national music culture.

\subsection{Improving college student self-experiencing ability}

Teaching materials of national music are limited. Music itself should be based on perceptual knowledge. Therefore, the study of national music should increase student independent experience and accumulate emotional experience, and constantly discover the beauty of national music under the guidance, establishing sublimation from perceptual knowledge to rational understanding, ultimately realizing the profound national music. Teaching should not emphasize the theory or rigidly adhere to analysis and explanation of music composition, melody development or singing 
methods. It is necessary to focus on student self-feeling, inspiring imagination, integrating enjoyment and emotional perception, making national music enjoyment one of the most important emotional experience activities. Only in this way, students will naturally have heartfelt appreciation and enjoyment, cultivating noble national principle.

\section{References}

[1] Tian-jian CHENG, Introduction to Chinese National Music, Shanghai, Shanghai Music College Publishing House, 2004

[2] Ai-qing YIN, Introductory Theory and Pedagogy of Teaching Materials of College Music Education, Beijing, People’s Music Publishing House, 2007. 